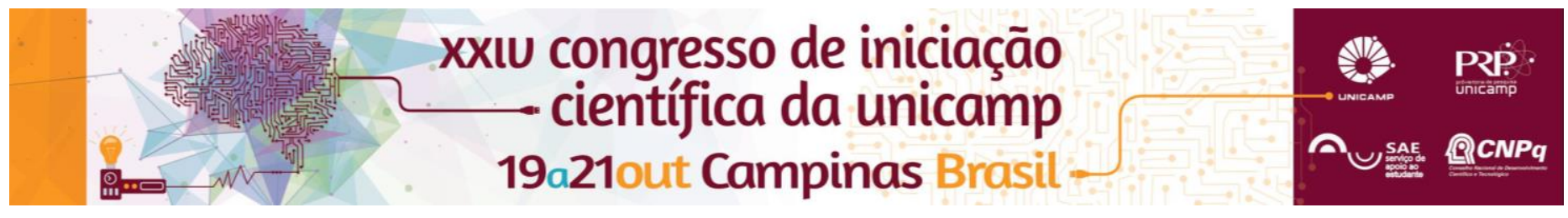

\title{
MAQUETES FÍSICAS DE ESTUDO NA IDEALIZAÇÃO DE PROJETOS ARQUITETÔNICOS.
}

\author{
Mayla Magaieski Graepp*, Hândrya Daniella Corrêa de Oliveira, Reicia Deucher Nunes
}

\section{Resumo}

O processo de idealização e desenvolvimento de um projeto arquitetônico, enquanto trabalho acadêmico, pode acorrer de diversas maneiras - o que de fato depende da metodologia de ensino aplicada nas disciplinas de projetos arquitetônicos e urbanísticos. Neste contexto, este trabalho busca discutir o emprego das maquetes físicas de estudo, como parte integrante do processo de criação e desenvolvimento de projetos arquitetônicos experimentados pelos alunos do Curso de Arquitetura e Urbanismo do Centro Universitário Adventista de São Paulo, campus Engenheiro Coelho - UNASP-EC.

\section{Palavras-chave:}

arquitetura e urbanismo, maquete física, projeto arquitetônico.

\section{Introdução}

A representação do projeto de arquitetura e urbanismo abrange um campo extremamente vasto de conhecimentos técnicos e expressivos. Como instrumento torna possível a descrição analítica das características construtivas e das operações necessárias para passar do projeto à realização. Portanto, o nível de comunicação que requer é especializado, além de utilizar linguagens, códigos e convenções acessíveis apenas a quem possui um conhecimento profundo da matéria (GONSALEZ, 2001).

As maquetes são representações tridimensionais com a função de gerar ideias de projeto e de servir como veículos para aperfeiçoamentos. As maquetes podem variar desde modelos físicos rápidos e rudimentares até modelos finalizados com alto nível de detalhamento (MILLS, 2007).

Este trabalho é um estudo de caso, que busca dar ênfase às vantagens relacionadas à adoção das maquetes físicas como parte integrante da metodologia de ensino da disciplina Projeto VII, experimentada por alunos do curso de Arquitetura e Urbanismo do UNASPEC durante o primeiro semestre de 2016.

\section{Resultados e Discussão}

No âmbito da disciplina Projeto VII, alunos do Curso de Arquitetura e Urbanismo do UNASP-EC tiveram a oportunidade de projetar com o auxílio de maquetes confeccionadas com materiais de baixo custo, como o isopor e o papel, durante todo o processo de desenvolvimento do projeto arquitetônico de uma edificação com finalidades culturais. Os detalhes inerentes às maquetes evoluíram concomitantemente ao projeto, subsidiando-o, desde os estudos preliminares.

Alunos relataram expressivos avanços no aprendizado, justamente em função do emprego das maquetes físicas. As Figuras 1, 2, 3 e 4 trazem um exemplo das maquetes confeccionadas por um dos alunos da referida disciplina. Tais relatos atestam que, a adoção das maquetes físicas durante o desenvolvimento do projeto, culminaram numa melhor percepção sobre: a) a relação entre a edificação e seu entorno; b) a relação entre a edificação e a topografia do terreno; c) os volumes e relações entre cheios e vazios; d) questões relacionadas ao conforto térmico e acústico; f) questões paisagísticas; e, f) qualidades abstratas do projeto arquitetônico.

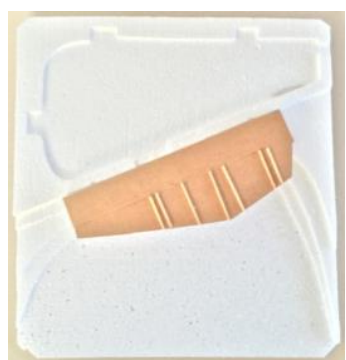

Figura 1. Maquete inicial (vista de topo)

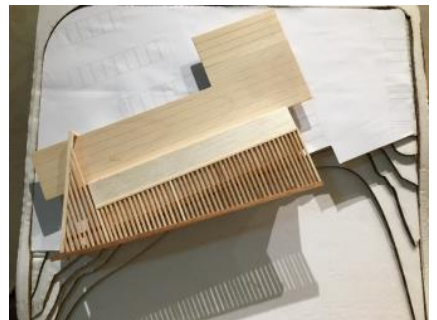

Figura 3. Maquete final (vista de topo)

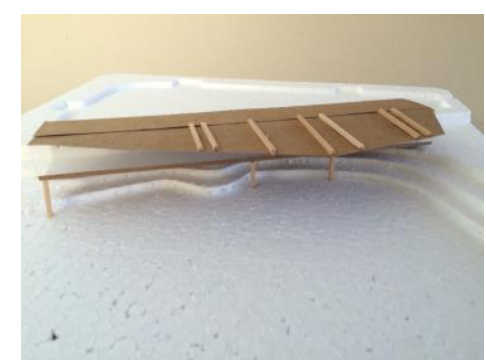

Figura 2. Maquete inicial (em perspectiva)

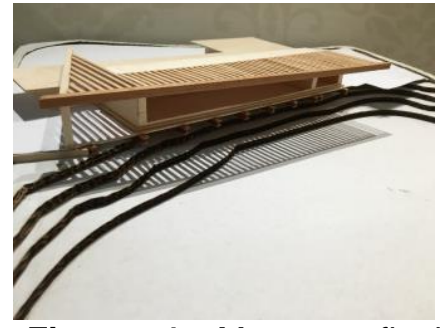

Figura 4. Maquete final (em perspectiva)

\section{Conclusões}

A utilização das maquetes físicas de estudo, subsidiou satisfatoriamente o processo de criação de projetos arquitetônicos acadêmicos. Confeccionadas com materiais de baixo custo, as maquetes fizeram parte de todo o processo, desde os estudos preliminares, evoluindo concomitante ao projeto.

Expressivos avanços no aprendizado foram relatados pelos próprios alunos, pois perceberam maiores facilidades, no que diz respeito à organização das ideias, na arte de se projetar.

\section{Agradecimentos}

Agradecemos ao Centro Universitário Adventista do Estado de São Paulo, por todas as modalidades de incentivos para a realização deste estudo.

GONSALEZ, Lorenzo. Maquetes: a representação do espaço no projeto arquitetônico. Barcelona: Gustavo Gilli, 2001.

MILLS, Criss B. Projetando com maquetes: um guia para a construção e o uso de maquetes como ferramenta de projeto. 2. ed. Porto Alegre: Bookman, 2007. 